\title{
POST MORTEM INSEMINATION AND EMBRYO TRANSFER, BEST INTERESTS AND THE CHILD'S RIGHTS: A REVIEW OF PORTUGUESE LAW AND PUBLIC POLICY
}

\author{
INSEMINAÇÃO PÓS-MORTEM E TRANSFERÊNCIA DE EMBRIÕES, OS \\ MELHORES INTERESSES E OS DIREITOS DA CRIANÇA: UMA REVISÃO DA \\ LEI PORTUGUESA E DA POLÍTICA PÚBLICA
}

Eva Dias Costa ${ }^{1}$

\begin{abstract}
The Portuguese law of medically assisted reproduction prohibits post mortem insemination. Post mortem transfer of ex utero embryos is also prohibited, with one exception: a previous written parental project. Nevertheless, if a child is born in violation of the rules, she is still considered the legal child of the donor.

The law has clearly been designed to on the one hand regulate reproduction while protecting the child on the other, but is the child born in violation of the rules afforded equal rights? And does the State have any business in regulating reproduction in the first place?

In order to answer these questions, we have analysed the Portuguese Civil Code against the more modern rules of medically assisted reproduction, in light of the Constitution and of international law. We also touch on the broader questions of the future child's best interests and the States' justification for regulating reproduction.
\end{abstract}

Key Words: Best interests; embryo transfer; insemination; post mortem; reproduction regulation; succession rights.

\section{RESUMO}

A lei portuguesa de reprodução medicamente assistida proíbe a inseminação post mortem. A transferência post mortem de embriões ex útero também é proibida, com uma exceção: um projeto prévio por escrito dos pais. No entanto, se uma criança nasce em violação às regras, ela ainda é considerada filha legal do doador. A lei foi claramente projetada para, por um lado, regular a reprodução e, ao mesmo tempo, proteger a criança, mas será que a criança nasce violando as regras garantidas por direitos iguais? E o Estado tem alguma função em regulamentar a reprodução em primeiro lugar? Para responder a essas questões, analisamos o Código Civil português à luz das regras mais modernas de reprodução medicamente assistida, à luz da Constituição e do direito internacional. Também abordamos as questões mais amplas

\footnotetext{
${ }^{1}$ Doutora em Direito Fiscal. Professora Auxiliar do Departamento de Direito e do Departamento de Economia, gestão e Informática da Universidade Portucalense. Investigadora Integrada do Instituto Jurídico Portucalense (Fundação Ciência e Tecnologia). Editora Adjunta da Revista Jurídica Portucalense. Advogada. Juiz-Árbitro em Matéria Tributária do Centro de Arbitragem Administrativa e Tributária (CAAD). Perita Convidada da Comissão Europeia - Direção Geral de Justiça. Universidade Portucalense Infante D. Henrique - Portugal. ORCID: https://orcid.org/0000-0003-0262-977X E-mail: eva@upt.pt
} 
do melhor interesse da futura criança e a justificativa dos Estados para regulamentar a reprodução.

Palavras-chave: Melhores interesses; transferência de embriões; inseminação; post mortem; regulamentação da reprodução; direitos de sucessão.

\section{INTRODUCTION}

\section{THE PORTUGUESE RULES FOR MEDICALLY ASSISTED REPRODUCTION}

In Portugal, paternity and maternity are determined either by voluntary declaration or by the courts as a result of a number of possible law suits which can be brought about against the presumed father or mother 2 .

Paternity can also be established by legal presumption: when a child is conceived or born in wedlock (a child is legally presumed to have been conceived in the first 120 days of a 300 days pregnancy, counted backwards from the moment of birth 3) the husband of the mother presumed juris tantum to be the father 4 . These rules have been in use since 1966, the date of the current Portuguese Civil Code, but were not much different in the old Civil Code of 1867.

The Portuguese law for Medically Assisted Reproduction was drafted in 2006, and has since been modified four times. The last important modification took place in 2017: it has made surrogacy legal 5. Since then, the Constitutional Court declared certain provisions about surrogacy to be unconstitutional and revoked it, and no new law has been passed in order to try and circumvent the objections of the court 6 .

The law also prohibits post mortem insemination 7, and the violation of this prohibition is a crime for doctors and medical staff, as well as for the mother. Nevertheless, if a child is born in violation of the prohibition, she is still the legal child of the of the sperm donor 8 .

Post mortem embryo transfer is also prohibited, and it is also a crime, but there is one important exception: if there was what the law calls a previous written parental project and the

\footnotetext{
${ }^{2} C f$. articles 1796 to 1873 of the Portuguese Civil Code. The updated oficial version is available here: https://dre.pt/legislacao-consolidada/-/lc/34509075/view.

3 Cf. article 1798 of the Portuguese Civil Code.

${ }^{4} \mathrm{Cf}$. article 1826 of the Portuguese Civil Code.

${ }^{5}$ Cf. Law 32/2016, 2006-07-26, article 2 and article 8.

ELI: https://data.dre.pt/eli/lei/32/2006/p/cons/20170725/pt/html.

${ }^{6} C f$. Acórdão do Tribunal Constitucional n. ${ }^{\circ} 465 / 2019,2019-10-18$, ELI: https://data.dre.pt/eli/actconst/465/2019/10/18/p/dre.

${ }^{7}$ Cf. Law 32/2016, article 22.

${ }^{8}$ Cf. Law 32/2016, article 20.
} 
father dies, the mother can still request the transfer of the embryo and has an undetermined, but necessarily short period to make that decision. If a child is born, they are still the legal child of the other consenting partner in the so-called parental project.

This happens even if the transfer is made in violation of the law. The law has clearly been designed to protect the child, but does it really offer enough protection and, conversely, should it offer such protection or is this inviting infraction?

Moreover, is the child really allowed equal rights as any other son or daughter of the donor born, conceived inside the fallopian tube or successfully transferred while he was still alive?

\section{THE PORTUGUESE LAW OF SUCCESSION}

Succession law in Portugal is rigid and imperative.

The system is ancient, very much influenced by roman law, and it protects the family even from the will of future de cujus: there is an important part of one's inheritance which is reserved for the immediate family, and in order to protect this even donations inter vivos are (albeit fictitiously) returned after death in order to calculate the inheritance one would have if it were not for those donations 9 .

In fact, one's inheritance is constituted, as in the old roman tradition (Justo 2010), of (relictum-debitum $)+$ donatum, and the immediate family have the right to between $1 / 3$ to $2 / 3$ (usually the later, for example, if one is survived by children and spouse) of the resulting amount. If inter vivos donations or mortis causa provisions offend this legal quota, i.e., exceed the allowed quota) they will be reduced in favour of the legitimate heirs (Telles 1971; Campos and Campos 2017).

The system was designed to protect the family, based on an idea of communal property and family solidarity (Telles 1971; Justo 2010; Campos and Campos 2017).

Since 1977, as a result of the 1974 revolution and the new Constitution which followed and imposed significant changes to the Portuguese Civil Code, the spouse is included in the list of people that have a legal right to a portion of one's inheritance (Pitão 2006).

\footnotetext{
${ }^{9} C f$. articles 2157 - 2162 of the Portuguese Civil Code.
} 


\section{DISCUSSION}

\section{LEGAL PERSONALITY, LEGAL CAPACITY AND CAPACITY TO SUCCEED: UNDERSTANDING THE DIFFERENCE}

In Portugal, in order to succeed - in fact, in order to be a legal person - one has to be born. In fact, the Portuguese Civil Code determines that legal personality is acquired at the moment of birth (when a child is completely separated, and alive), and ends with death.

Therefore, the child in the womb is not a legal person under the Portuguese Civil law, although there is a certain amount of protection for the unborn child, and some argue (Costa, Eva Dias; Campos 2015) that the unborn child's legal personality is subject to a resolutive condition (of being born alive), rather than a suspensive condition. A child still in the womb will have a right to succeed if she is born alive or a child has the right to succeed unless she is not born alive is the relevant distinction here.

Regarding legal personality, the Code presents the interpreter with a difficulty: it distinguishes legal personality from (what can be loosely translated as) fruition capacity. It is likely the result of a deficient translation of Rechtsfähigkeit, from the German Bürgerliches Gesetzbuch that so inspired the Portuguese Civil Code of 1966 (Vasconcelos 2017).

This fruition capacity consists of the susceptibility of the legal person to be the subject of rights and obligations, and is also different from legal capacity, which is acquired at the legal age of majority (currently, 18). One cannot have personality and be totally devoid of fruition or even legal capacity, but that does not go so far as to say that these three concepts are the same.

The distinction is extremely important: the quality of being a person cannot be denied, even when that there are certain natural or limitations regarding a person's fruition and/or legal capacity. Such limitations might include being in our mother's womb, being dead or being cryopreserved in the blastocyst stage.

The fact is that the Portuguese rules of succession where written long before medically assisted reproduction was possible, let alone common. The right to succeed belongs to a child that was conceived before death, even if she is born after the death of the father, and that happens clearly because de law makers could not even phantom post mortem conception.

So, a child born of post mortem insemination does not seem have the right to succeed her father. 
On the contrary, an embryo transferred post mortem was already conceived at the time of the father's death, and therefore seems to have the right to succeed, the problem being that they probably not be born within the legal period of pregnancy, i.e., 300 days, and that the law makers also did not have in mind that an egg could be fertilized and that the embryo could be cryopreserved - perhaps indefinitely - and at a future date transferred into a woman's uterus with the intent to establish a pregnancy, and certainly not that it could happen after the father was deceased.

That is not what they had in mind when they wrote that in order to have the ability to succeed a parent the child must be already born or at least conceived at the moment of the parent's death.

They also did not have in mind the possibility of post mortem insemination when they wrote that although a child that is not yet conceived at the moment of death does not have the automatic, legal, right to succeed the parent, a provision can be made in a will in favour of someone who has not yet been conceived but is the child of a certain, identified person. The law makers thought of this possibility for different instances - one wants to benefit the future son or daughter of a brother, for example -, surely not in order to allow one to benefit one's future son or daughter, born by means of artificial insemination with donated sperm after one is dead.

\section{THE VERY OLD AND THE VERY NEW: A DIFFICULT COEXISTENCE}

These circumstances may seem strange to an outside observer. They are very particular to Portugal, a very old country - one of the oldest in the world - with stable borders for centuries and a strong sense of national identity and tradition, with a continental law system influence first by roman law and then by Canon Law.

Portuguese succession law still bears the mark of roman successione and Portuguese family law, the mark of the Roman Catholic Church (Campos 1995).

Nevertheless, Portuguese society has evolved, particularly joining in 1985 what was then the European Economic Community.

Portugal is today a modern member of the European Union, and has for the most part been governed by centre left, progressive parties or coalitions. As a result, divorce was made 
easier in 2008, same sex marriages are allowed since 2010 10, same sex adoption rights have been granted in 2016 11, and in that same year - be it not for the Constitutional Court - Portugal would have been one of the few countries in Europe to allow surrogacy pregnancies.

Law makers in Portugal have a peculiar way of going about their business, particularly when driven by ideology and in possession of a weak majority in Parliament.

They propose small amendments to existing laws, and rarely make serious reforms or give a thought to the needs of the desired axiological unity of the system.

The result is that the law - especially family law - is a strange mosaic of the very old and traditional and the very new and modern, a hybrid creature whose arms and legs cannot move in unison (Costa 2019).

\section{PRIVATE INTERNATIONAL LAW AND REPRODUCTION TOURISM}

Because Portugal is part of the European Union, where all European citizens can travel, live and work freely, this state of affairs is complicated further.

A German couple's embryo might be cryopreserved in a fertility clinic in Lisbon, and be legally - albeit exceptionally - transferred to the mother's uterus even after the father is dead. Even if the child is born in Portugal, she is still a German and not a Portuguese national as a result of the jus sanguinis rule.

That she is the couple's legal child is doubtful under German law (Krüger 2011), but would be certain under Portuguese law. Determining which law would be applicable to the question of paternity, parental judgments and responsibilities would be a conflict between Portuguese and German law. This conflict would have to be resolved under private international law rules in conjugation with Regulation (EC) No 2201/2003 - jurisdiction, recognition and enforcement of matrimonial and parental judgments and Regulation (EU) No 650/2012 of the European Parliament and of the Council of 4 July 2012 on jurisdiction, applicable law, recognition and enforcement of decisions and acceptance and enforcement of authentic instruments in matters of succession.

\footnotetext{
${ }^{10} \mathrm{Cf}$. article 1733 of the Portuguese Civil Code.

${ }^{11} C f$. Law 2/2016, 29.02.2016, ELI: https://data.dre.pt/eli/lei/2/2016/02/29/p/dre/pt/html.
} 
In spite of these problems, the fact is that the embryo might be transferred in Portugal if there is a previous written parental project 12-, and it would not in many other European countries, and that remains an important reason for reproductive tourism within the European Union (European Society of Human Reproduction and Embryology (ESHRE) [n.d.]).

The problem is addressed by the Convention of 19 October 1996 on Jurisdiction, Applicable Law, Recognition, Enforcement and Co-operation in respect of Parental Responsibility and Measures for the Protection of Children - in much broader terms than those of the EU member-states alone - and is currently being studied by the Permanent Bureau of the Hague Conference on Private International Law (Hague Conference on Private International Law 2019).

If Portuguese law is applicable to the determination of parentage and to succession rights of the child the problem persists: the law only states that if there is a post mortem insemination or embryo transfer the child is the son or daughter of the deceased sperm donor/father, but does not explicitly state how paternity is to be determined.

Even if the mother was married to the sperm donor/father, the child was not born - and in the case of post mortem fertilization, was not conceived - during the marriage, so paternity cannot be established by legal presumption.

In the case of post mortem transfer, the child might have been conceived during the marriage only if one equates fertilization, conception, and pregnancy. They are nevertheless not the same thing, and in legal terms a conceived child means-rather, it certainly meant, when the law was written - a pregnant mother.

The mother's declaration will not suffice, the donor/father cannot have declared that he is the father of an unborn child (even in his will) and all that is left is a judicial investigation. The future of the child is in the hands of the court, which must do its best with fragmented law to determine paternity.

The question of the right of the child to their father's inheritance is yet another matter and will most likely trigger another court case. The court must then decide if the transferred embryo can be considered to have been conceived before the father died, which really means conceived in the sense the law initially intended.

\footnotetext{
12 This is a direct translation of the expression projeto parental. The law does not define, however, what exactly does a parental project consist of.
} 
The court may well decide that an embryo transferred post mortem was conceived ante mortem and is therefore allowed the right to succeed, but it cannot possibly say that an egg fertilized post mortem is a child conceived ante-mortem.

Nevertheless, those children might be born. Within the limits of the law or in violation of it, they can in fact very easily be born. And if they are, must not they have the same legal rights as any other children, conceived inside the fallopian tube (or at least, successfully transferred) before their fathers died?

The principle of equal treatment, equal rights, the prohibition of discrimination present in the Portuguese Constitution and in multiple international treaties which Portugal has signed or is subject to under the Treaty of the EU demand it, even if it means going well beyond the limits of the written law on the subject.

If not ipsis litteris or ipsis verbis, the child born under such circumstances is protected ipso iuri et iure proprio.

\section{THE PROBLEM WITH THE CONCEPT OF THE WELFARE OF THE FUTURE CHILD}

Notwithstanding, succession law in Portugal must follow suit to family law and be adapted to modern times, modern families and modern medicine.

Modern mothers, fathers and couples, however, need to seriously reflect on the ethical considerations and practical consequences of these parental projects if they are allowed to continue even beyond death, as children born of these decisions are a priori and forever condemned by one of the parents to a life without the other parent.

The issue of post-mortem insemination first came into focus in Europe in 1984, following the death of Alain Parpalaix, a citizen of France, who, at twenty-four, was suffering from testicular cancer and undergoing chemotherapy. His doctor warned him that the treatment would render him sterile, and he made one "deposit" of sperm at the Centre d'Etude et de Conservation du Sperme (CECOS), a government backed research centre and sperm bank, but left no instructions as to the future use of the sperm. His widow requested the sperm from CECOS, where it had been stored, frozen in liquid nitrogen, but was denied and resorted to the courts. The Court de grand instance was quick to warn of the difficulties that French laws 
governing inheritance rights and illegitimacy would impose on a child born post mortem 13 , but aknowledged the laws were outdated and granted the widow's wish citing a fundamental right to procriation (E. Donald Shapiro and Benedene Sonnenblick [n.d.]).

Surely one must wonder if such a decision is indeed was in the best interests of the child.

There is a reason why the law prohibits post mortem insemination and seriously limits post mortem embryo transfer. The difference of treatment between the two is of course obvious and justified, but should it really prohibit either?

Whose interests is the law protecting? The heirs' interests, the extended family's interests, the stability of family relationships and ownership or the future child's interests?

Is being born without a living father to help one through life better than not being conceived or have been destroyed in embryonic state, better than not being born at all? Would the child's life not be worth living? And if the State can decide which lives are worth living, why stop at medically assisted reproduction? Why not allow euthanasia of new-borns with serious health problem, as they do in the Netherlands (Verhagen and Sauer 2005; Eduard Verhagen 2014; Tedesco 2017)?

In fact, the State might be justified in prohibiting post mortem insemination and embryo transfer if one considers the families' interests and society's general interest in the stability of legal rights and relations (McLean 1997). In a rigid succession system as the Portuguese is - or even in a more liberal one - there is a legitimate interest in the certainty and stability of the transmission of property mortis causa.

Praescriptio and usucapio in Roman Law were justified by the need for peace and stability, as they were later in Canon Law and are to this day. However, both the ancient and the current statutes of limitation were created with the normal, natural lifespan in mind. They do not take into account the possibility of frozen gametes or embryos, nor the advances of modern science. Legislators in Roman times, in medieval times or even in the 1960s could not fathom that a woman could carry a child to term well into her seventies (Arshad R. Zargar and Welch 2016).

\footnotetext{
${ }^{13}$ In France, as in Portugal, a child born more than 300 days after her father's death does not benefit from the presuntion of paternity - cf. article 315 of the French Civil Code and the combination of articles 1798 and 1826 of the Portuguese Civil Code. And in France, as in Portugal, the child must exist at the time of the father's death in order to suceed. Regarding medically assisted procriation, article 311-20 (which was not in Effect at the time of Monsier Parpalaix' death) of the French Code Civil states that any consent given to medically assisted procriation ceases with death.
} 
There are also issues of distributive justice at stake. Medically assisted reproduction is largely State funded in Portugal. Indeed, healthcare is mostly State funded (de Almeida and others 2017), and the Portuguese Health Care System is both chronically and increasingly (due to population decline combined with scientific advances and climbing costs) underfunded (Costa and Pinho 2020).

Moreover, children born without the financial support of one of the parents will likely be a burden on the fragile social security system (Banks 1999).

Those issues are certainly legitimate, but one must be aware of the attraction (Cohen 2012) of the best interest of the future child justification.

\section{CONCLUSION: WHOSE BEST INTERESTS?}

The future child's welfare or best interests view is as attractive in family law - and as palatable to the general public - as the principle of autonomy is regarding voluntary euthanasia (Costa and Campos 2018).

It is indeed morally soothing and uncannily useful that the social engineering impetus of the State should be so in tune with legitimate ethical considerations of distributive justice as well as seemingly altruistic reasons.

It is difficult to accept that there are wrong lives, persons who should not be - or should not have been - born. What is even more worrying is that the State be allowed to decide which ones.

As many have shown, a decision not to allow a child into existence cannot be in their best interest (Cohen 2012; ten Haaf 2016; Jackson 2008; Walker 2014; Feinberg 1986). In fact, as Parfit has famously demonstrated with his non-identity problem, it is a logical impossibility (Parfit 1986).

Nevertheless, such a decision can still be justified, as indeed it might be in the case of post mortem fertilization or embryo transfer prohibition we have been discussing. But if it is indeed justified, we must not deceive ourselves: it is so in the interests of the living. 


\section{REFERENCES}

de Almeida, Jorge, Simões Gonçalo, Figueiredo Augusto, Inês Fronteira, and Cristina Hernández-Quevedo. 2017. Health Systems in Transition - Portugal, Portugal Health System Review, XIX [accessed 4 August 2020]

Arshad R. Zargar, and Ashley Welch. 2016. "Woman in Her 70s May Be Oldest Ever to Give Birth," CBS News <https://www.cbsnews.com/news/woman-in-her-70s-may-be-oldest-ever-togive-birth/>

Banks, G. J. 1999. "Traditional Concepts and Nontraditional Conceptions: Social Security Survivor's Benefits for Posthumously Conceived Children," Loyola Los Angeles Law Review: 251-379 <https://pubmed.ncbi.nlm.nih.gov/12455504/> [accessed 4 August 2020]

Campos, Diogo Leite de. 1995. A Invenção Do Direito Matrimonial (Almedina)

Campos, Diogo Leite de, and Mónica Martinez de Campos. 2017. Lições de Direito Das Sucessões (Almedina)

Cohen, I. Glenn. 2012. "Regulating Reproduction: The Problem with Best Interests," Minnesota Law Review: 423-519

Costa, Eva Dias. 2019. "Fraturas Do Direito Matrimonial Português Contemporâneo: Opinião a Propósito Do Acórdão Do Tribunal Da Relação Do Porto de 25 de Junho de 2019," Direito Em Dia

Costa, Eva Dias, and Diogo Leite de Campos. 2018. "O Direito à Vida Implica o Direito a Morrer? Pessoa e Eutanásia,” Revista Da Ordem Dos Advogados, III/IV

Costa, Eva Dias; Campos, Mónica Martinez de. 2015. “A Proteção Ao Nascituro Na Constituição, Na Legislação Ordinária e Na Moderna Jurisprudência Portuguesa e Brasileira Análise Comparativa," Cadernos de Dereito Actual (ES): 117 a 135 <http://cadernosdedereitoactual.es/ojs/index.php/cadernos/article/view/38>

Costa, Eva Dias, and Micaela Pinho. 2020. "Does Implicit Healthcare Rationing Impose an Unfair Legal Burden on Doctors? A Study of Portuguese Jurisprudence," Medical Law International, 20.1: 31-57<https://doi.org/10.1177/0968533220927441>

E. Donald Shapiro, and Benedene Sonnenblick. [n.d.]. "Widow and the Sperm: The Law of Post-Mortem Insemination Benedene Sonnenblick," Journal of Law and Health Law Journals $<$ https://engagedscholarship.csuohio.edu/jlh> [accessed 4 August 2020]

Eduard Verhagen, A.A. 2014. "Neonatal Euthanasia: Lessons from the Groningen Protocol," Seminars in Fetal and Neonatal Medicine, 19.5: 296-99

<https://doi.org/10.1016/j.siny.2014.08.002> 
European Society of Human Reproduction and Embryology (ESHRE). [n.d.]. Comparative Analysis of Medically Assisted Reproduction in the EU: Regulation and Technologies (SANCO/2008/C6/051)

<https://ec.europa.eu/health/sites/health/files/blood_tissues_organs/docs/study_eshre_en.pdf> [accessed 4 August 2020]

Feinberg, Joel. 1986. "Wrongful Life and the Counterfactual Element in Harming," Social Philosophy and Policy, 4.1: 145-78 <https://doi.org/10.1017/S0265052500000467> ten Haaf, Lisette. 2016. "Future Persons and Legal Persons: The Problematic Representation of the Future Child in the Regulation of Reproduction," Laws, 5.1: 10

<https://doi.org/10.3390/laws5010010>

Hague Conference on Private International Law. 2019. "The Parentage/Surrogacy Project" <https://www.hcch.net/en/projects/legislative-projects/parentage-surrogacy/> [accessed 19 June 2019]

Jackson, Emily. 2008. "Conception and the Irrelevance of the Welfare Principle," The Modern Law Review, 65.2: 176-203 <https://doi.org/10.1111/1468-2230.00374>

Justo, A. Santos. 2010. Direito Privado Romano - V Direito Das Sucessões e Doações (Coimbra EDitora)

Krüger, Matthias. 2011. "The Prohibition of Post-Mortem-Fertilization, Legal Situation in Germany and European Convention on Human Rights," Revue Internationale de Droit Pénal, 82.1: 41 <https://doi.org/10.3917/ridp.821.0041>

McLean, S. 1997. "Symposium: Reference Documents on the Ethics and Laws of Human Reproduction. Consent and the Law: Review of the Current Provisions in the Human Fertilisation and Embryology Act 1990 for the UK Health Ministers," Human Reproduction Update, 3.6: 593-621 <https://doi.org/10.1093/humupd/3.6.593〉

Parfit, Derek. 1986. Reasons and Persons (Oxford University Press) <https://doi.org/10.1093/019824908X.001.0001>

Pitão, José António França. 2006. A Posição Do Cônjuge Sobrevivo No Actual Direito Sucessório Português (Almedina)

Tedesco, Matthew. 2017. "Dutch Protocols for Deliberately Ending the Life of Newborns: A Defence," Journal of Bioethical Inquiry, 14.2: 251-59 <https://doi.org/10.1007/s11673-0179772-2>

Telles, Inocêncio Galvão. 1971. Direito Das Sucessões - Noções Fundamentais (Lisboa: Faculdade de Direito da Universidade de Lisboa)

Vasconcelos, Pedro Pais de. 2017. Direito Da Personalidade, ed. by Almedina Verhagen, Eduard, and Pieter J.J. P.J.J. Sauer. 2005. "The Groningen Protocol — Euthanasia in Severely Ill Newborns," New England Journal of Medicine, 352.10: 959-62

<https://doi.org/10.1056/NEJMp058026> 
Quaestio Iuris

vol.13, n-.03, Riode Janeiro, 2020. pp. 1219-1230 DOI: $10.12957 /$ rqi.2020.45898

Walker, Samuel E. P. 2014. "Potential Persons and the Welfare of the (Potential) Child Test," Medical Law International, 14.3: 157-71 <https://doi.org/10.1177/0968533214550117>

Trabalho recebido em 04 de agosto de 2020

Aceito em 05 de agosto de 2020 